\title{
The Effect of E-Service Quality toward Customer Satisfaction: PlayStation Store
}

\author{
As'adahullah Khairul Alam ${ }^{1}$, Adhi Prasetio ${ }^{2}$ \\ ${ }^{1}$ International ICT Business, Faculty of Economics and Business, Telkom University \\ ${ }^{2}$ Faculty of Economics and Business, Telkom University
}

\begin{abstract}
A large population of internet users caused the online shopping became more popular nowadays. Not only by shopping physical goods through internet, people now can also purchase and pay for services online, for example by purchasing digital contents through a website. The example for this event is PlayStation Store. Sony PlayStation Store offers digital contents such as base game (digital game), and DLCs (Downloadable Contents) on their site since 2006. PlayStation Store site allows PSN users to provide feedback if they have problems with the PlayStation Network services. Most reported problems that were found in PlayStation Network consists of Sign-in (77\%), Game play (11\%), and PlayStation Store (10\%).The objective of this study is to analyze and to observe the effect of online service quality (e-SQ) toward customer satisfaction using PlayStation Store as an application within this research. Five dimensions of e$S Q$ are used in this research such as: Efficiency, Reliability, System Availability, Fulfillment, and Privacy.This research used multiple regression analysis with the sample of 385. The most influential variable is Privacy with regression coefficient of 0.372, and System Availability with regression coefficient of 0.219, followed by Reliability with regression coefficient of 0.172 , and Efficiency with regression coefficient of 0.129 , meanwhile the very least influential is Fulfillment with -0.043 .Based on the overall analysis, Sony PlayStation need to improve every aspect related to the Fulfillment variable, which is to provide better service that includes availability, and delivery time to the customer. With these improvements, Sony PlayStation Store would create a better environment regarding to the Fulfillment of products/services toward Customer Satisfaction.
\end{abstract}

Keywords: e-Service Quality, e-Commerce, Customer Satisfaction, PlayStation Store.

\section{Introduction}

A large population of internet users caused the online shopping become more popular nowadays. Not only by shopping physical goods through internet, people now can also purchase and pay for services online, for example by purchasing digital contents through a website. The example for this event is PlayStation Store. Sony PlayStation Store offers digital contents such as base game (digital game), and DLCs (Downloadable Contents) on their site since 2006.

PlayStation Store site allows PSN users to provide feedback if they have problems with the PlayStation Network services. Unfortunately, problems were found during the service delivered to the customer. Most reported problems that were found in PlayStation Network consists of Sign-in (77\%), Game play (11\%), and PlayStation Store (10\%). ${ }^{[11]}$

A good service that is provided by the company will lead into the enhanced customer satisfaction. According to Parasuraman, Zeithaml, and Berry (1988), "Customer satisfaction can be measured by five aspects that is knownwell as TERRA (Tangibles, Empathy, Responsiveness, Reliability, and Assurance). In terms of e-commerce, service quality may be different with the TERRA concept of service quality, such as Efficiency, Reliability, Responsiveness, Fulfillment, and Privacy.", based on Saha, P. and Zhao, Y. (2005). ${ }^{[5]}$
The number of gamers in Indonesia is increasing from time to time. Of 126 million gamers, 60 million spend money on games. Last year, these 60 million consumers spent an average of $\$ 18.40$ on games annually. As KPIs differ drastically per country in Southeast Asia, Newzoo believes Thailand will remain the largest games market in terms of revenues come 2017, followed closely by Indonesia and Malaysia. Similarly, Vietnam is expected to grow in line with the overall market to maintain its market share of 14 percent. Singapore will continue to grow, but lose some of its market share to faster growing countries, namely Indonesia and the Philippines. (TechinAsia.com, 2016) ${ }^{[8]}$

Table 1: Games Revenue Growth in Southeast Asia, Source: Newzoo (2016)

\begin{tabular}{|c|c|c|c|c|c|c|}
\hline \multirow{2}{*}{ Country } & \multicolumn{5}{|c|}{ Revenue } & \multirow{2}{*}{ CAGR } \\
\cline { 2 - 7 } & 2013 & 2014 & 2015 & 2016 & 2017 & \\
\hline Indonesia & $16 \%$ & $17 \%$ & $18 \%$ & $19 \%$ & $21 \%$ & $+37.3 \%$ \\
\hline Malaysia & $19 \%$ & $20 \%$ & $19 \%$ & $19 \%$ & $18 \%$ & $+27.0 \%$ \\
\hline Philippines & $9 \%$ & $9 \%$ & $9 \%$ & $10 \%$ & $11 \%$ & $+14.4 \%$ \\
\hline Thailand & $19 \%$ & $18 \%$ & $17 \%$ & $14 \%$ & $12 \%$ & $+30.9 \%$ \\
\hline Vietnam & $21 \%$ & $21 \%$ & $21 \%$ & $22 \%$ & $22 \%$ & $+27.2 \%$ \\
\hline Rest of SEA & $1 \%$ & $1 \%$ & $2 \%$ & $2 \%$ & $2 \%$ & \\
\hline Total & $\$ 806 \mathrm{M}$ & $\$ 1,094 \mathrm{M}$ & $\$ 1,413 \mathrm{M}$ & $\$ 1,767 \mathrm{M}$ & $\$ 2,216 \mathrm{M}$ & $+28.8 \%$ \\
\hline
\end{tabular}




\section{International Journal of Science and Research (IJSR) \\ ISSN (Online): 2319-7064}

Index Copernicus Value (2015): 78.96 | Impact Factor (2015): 6.391

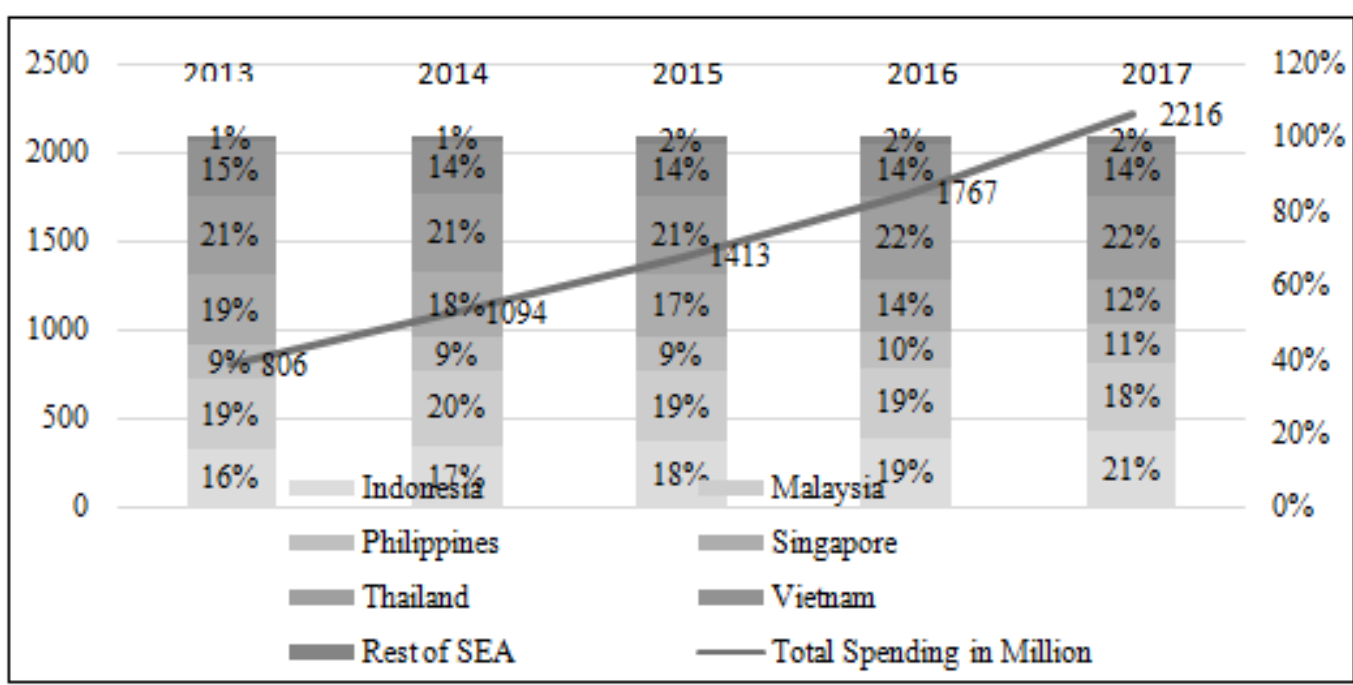

Figure 1: Southeast Asian Gaming Market 2013-2017

Indonesia has 66 million online population. The Indonesian games market is expected to generate revenues of $\$ 321$ million in 2015. This is a 56 million increase in 2014, making Indonesia the $24^{\text {th }}$ largest games market in the world and second in Southeast Asia. Of the 42.8 million gamers in Indonesia, 24.1 million spend money on games, a payer-toplayer ratio of $56 \%$, above the regional average. However, the annual average spend per payer of $\$ 13.30$ is below average. Total revenues will grow towards 2018 with a CAGR (Compound Annual Growth Rate) of $+45.7 \%$. (Newzoo.com $)^{[2]}$
According to Statista $(2016)^{[6]}$; Figure 1.3., current PlayStation gaming platform available in the market (PS4) is categorized on the third position in the most important gaming platforms in 2016 after PC, and Smartphones/Tablets. Gaming industry's competition is very tight especially with the current situation; existence of PC (Steam) and Smartphones/Tablets (Android and iOS). Meanwhile, PS4 is over-performed against Xbox One (Microsoft).

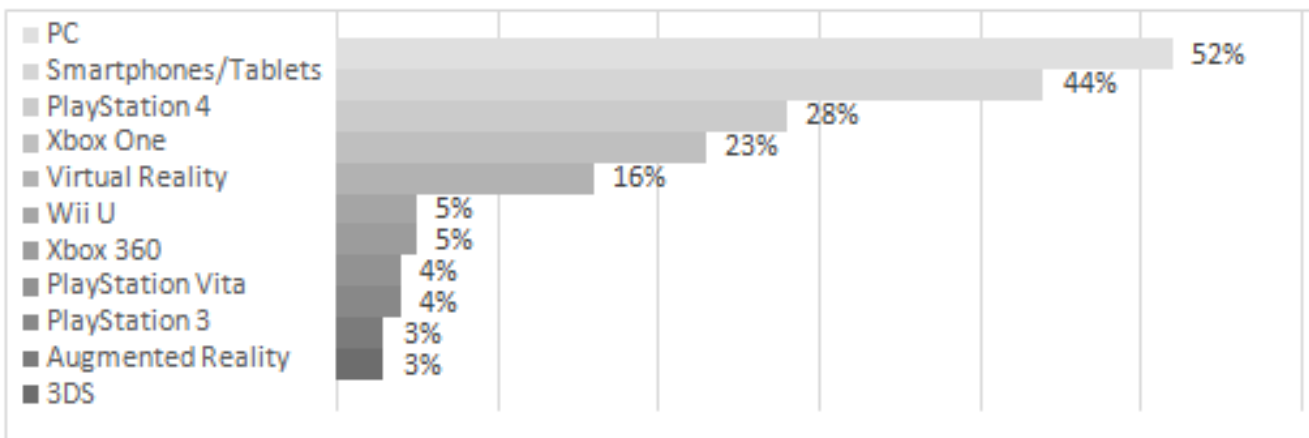

Figure 2: The Most Important Gaming Platforms in 2016

As of $6^{\text {th }}$ February 2017, gaming software units sold globally (excluding USA, Europe (UK, Germany, and France), and Japan) as follows ${ }^{[9]}$ :

Table 2: Global Gaming Software \& Hardware Sales Yearly

\begin{tabular}{|c|c|c|c|c|}
\hline Platform & $\begin{array}{c}\text { Software } \\
\text { Sales } \\
\text { Yearly } \\
\text { (in million) }\end{array}$ & $\begin{array}{c}\text { Total } \\
\text { Software } \\
\text { Sales } \\
\text { (in million) }\end{array}$ & $\begin{array}{c}\text { Hardware } \\
\text { Sales Yearly } \\
\text { (in million) }\end{array}$ & $\begin{array}{c}\text { Total } \\
\text { Hardware } \\
\text { Sales } \\
\text { (in million) }\end{array}$ \\
\hline $\begin{array}{c}\text { Sony } \\
\text { PlayStation 4 }\end{array}$ & 18 & 372.87 & 2.1 & 55.9 \\
\hline $\begin{array}{c}\text { Microsoft } \\
\text { Xbox One }\end{array}$ & 5.72 & 186.97 & 0.76 & 28.7 \\
\hline $\begin{array}{c}\text { Nintendo } \\
\text { Wii U }\end{array}$ & 1.4 & 88.2 & 0.58 & 13.8 \\
\hline
\end{tabular}

Based on the Table 1.2, we can conclude that most of games are sold from PS4 platform (Sony) with the highest number than Microsoft Xbox One. Therefore, the gaming ecosystem in PS4 platform is higher than Xbox One and Nintendo Wii U ecosystem.

\section{Research Framework}

Suriasumantri (1986) and Sugiyono (2009) stated that a researcher need to master scientific theoris as a conceptual framework structure basis that will result hypotheses. Conceptual framework is a temporary explanation toward problem statement symptoms. (Sujarweni, V. W., 2015:6667). ${ }^{[7]}$

In this research, the author adopted a conceptual framework from Saha, P., and Yanni, Z. (2005) on their research entitled: Relationship between Online Service Quality and Customer Satisfaction. ${ }^{[5]}$ The framework consists of Online Service Quality Dimensions (Efficiency, Reliability, System Availability, Fulfillment, and Privacy) ${ }^{[3][4][10]}$ variables and Customer Satisfaction in PlayStation Store variable based on Parasuraman et. al. (2005) ${ }^{[3]}$. Consequently, the author made some changes on Saha, P. (2005) framework from Responsiveness to System Availability since PlayStation 


\section{International Journal of Science and Research (IJSR) \\ ISSN (Online): 2319-7064}

Index Copernicus Value (2015): 78.96 | Impact Factor (2015): 6.391

Store only providing digital contents not physical goods and there are no physical goods return in their service. The conceptual framework stated as follows:

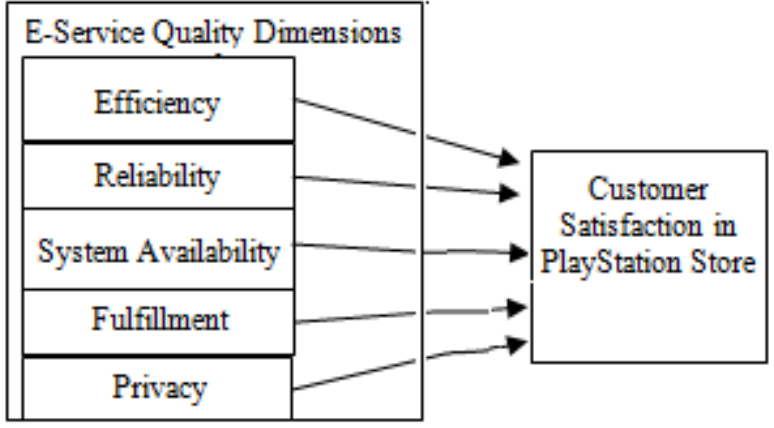

Figure 3: Conceptual Framework

\section{Research Hypothesis}

H1: Efficiency has a positive impact to the satisfaction of PlayStation Store customer.

H2: Reliability has a positive impact to the satisfaction of PlayStation Store customer.

H3: System Availability has a positive impact to the satisfaction of PlayStation Store customer.

H4: Fulfillment has a positive impact to the satisfaction of PlayStation Store customer.

H5: Privacy has a positive impact to the satisfaction of PlayStation Store customer.

\section{Research Method and Result}

This study collected data from 385 respondents to test hypotheses by using online questionnaire distributed to respondents. For data processing, the author used IBM SPSS Statistics version 23 for Windows. In IBM Statistics Data Editor. several tests were conducted such as Normal Distribution Test, Multicollinearity Test, Heteroscedasticity Test, and Multiple Regression Analysis before testing Hypotheses using $\mathrm{T}$ Test, $\mathrm{F}$ Test, and Coefficient of Determination (R2). Following are results of several tests conducted

Table 3: Skewness and Kurtosis

\begin{tabular}{|l|c|c|c|c|c|}
\hline \multicolumn{6}{|c|}{ Descriptive Statistics } \\
\hline & $\mathrm{N}$ & \multicolumn{2}{c|}{ Skewness } & \multicolumn{2}{c|}{ Kurtosis } \\
\cline { 2 - 6 } & Statistic & Statistic & Std. Error & Statistic & Std. Error \\
\hline eService_Quality & 385 & -.318 & .124 & .242 & .248 \\
\hline Valid N (listwise) & 385 & & & & \\
\hline
\end{tabular}

Based on Table 4.10, Skewness is -0.318 and Kurtosis is 0.242 . Therefore, $z_{\text {skewness }}$ and $z_{\text {kurtosis }}$ resulted as follows:

$$
\begin{aligned}
z_{\text {skewness }}=\frac{\text { skewness }}{\sqrt{\frac{6}{N}}} & z_{\text {kurtosis }} & =\frac{\text { kurtosis }}{\sqrt{\frac{24}{385}}} \\
z_{\text {skewness }}=\frac{-0.318}{\sqrt{\frac{6}{385}}} & z_{\text {kurtosis }} & =\frac{0.242}{\sqrt{\frac{24}{385}}} \\
=-2.547 & & =0.969
\end{aligned}
$$

This research has a normal distribution, since it has $z_{\text {skewness }}=-2.547$, which is less than +1.96 and $z_{\text {kurtosis }}=$ 0.969 , which is less than +1.96 . Another normality test can be also tested by using Kolmogorov-Smirnov Test as follows:
Table 4: Kolmogorov-Smirnov Test

One-Sample Kolmogorov-Smirnov Test

\begin{tabular}{ll|r|r|}
\hline & $\begin{array}{c}\text { Customer_Sa } \\
\text { tisfaction }\end{array}$ & $\begin{array}{c}\text { eService_Qua } \\
\text { lity }\end{array}$ \\
\hline $\mathrm{N}$ & 385 & 385 \\
Normal Parameters ${ }^{\mathrm{a}, \mathrm{b}}$ & Mean & 16.95 & 78.38 \\
& Std. Deviation & 2.327 & 9.904 \\
Most Extreme Differences & Absolute & .124 & .062 \\
& Positive & .108 & .062 \\
& Negative & -.124 & -.054 \\
Test Statistic & .124 & .062 \\
Asymp. Sig. (2-tailed) & $.000^{\mathrm{C}}$ & $.001^{\mathrm{C}}$ \\
\hline a. Test distribution is Normal. \\
b. Calculated from data. \\
c. Lilliefors Significance Correction.
\end{tabular}

Based on Table 4, the result of Asymptotic Significance of Customer Satisfaction is $0.000^{c}$ and e-Service Quality dimension is $0.001^{\mathrm{c}}$ because of the Lilliefors Significance Correction. Therefore, the result cannot be determined. However, another way to determine normal distribution is by performing examination using P-P Plot Graph. The result of linear regression analysis using Normal P-P Plot Graph already shown the pattern is normal. A normal distribution is a data that formed spread points which are not far from the diagonal line. Following is the P-P Plot Graph based on this research:

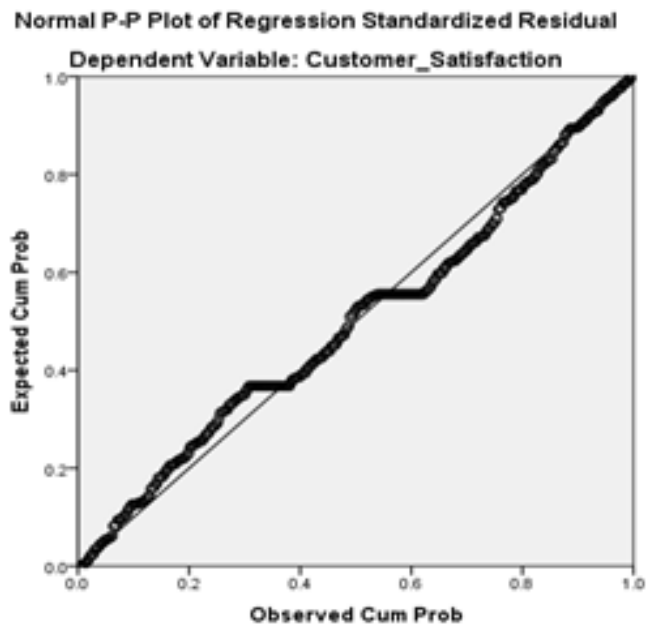

Figure 4: Normal P-P Plot

Based on figure 4, the regression model has a normal distribution because of the placement of dots are close to the diagonal line. In addition, this research has a normal distribution based on the P Plot Test result as follows:

Table 5: P Plot Test

Model Description

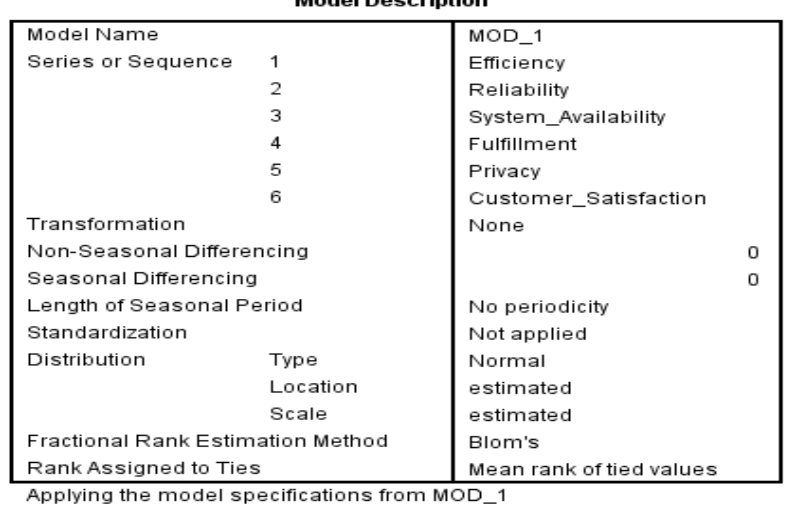

Volume 6 Issue 7, July 2017 www.ijsr.net 


\section{International Journal of Science and Research (IJSR) \\ ISSN (Online): 2319-7064}

Index Copernicus Value (2015): 78.96 | Impact Factor (2015): 6.391

\section{Multicollinearity Test}

Multicollinearity test can be done by using VIF. Indicated multicollinearity variable can be recognized from the VIF that is high on independent variables within a regression model. VIF value of independent variables in regression model are shown below:

Table 6: Multicollinearity Test

\begin{tabular}{|c|c|c|}
\hline Independent Variable & VIF & Explanation \\
\hline Efficiency & 2.355 & Non-multicollinearity \\
\hline Reliability & 2.776 & Non-multicollinearity \\
\hline System Availability & 2.519 & Non-multicollinearity \\
\hline Fulfillment & 2.436 & Non-multicollinearity \\
\hline Privacy & 2.301 & Non-multicollinearity \\
\hline
\end{tabular}

Based on the result above, all VIF from each independent variable has value below 10 . Therefore, the regression model in this research has no symptoms of multicollinearity.

\section{Heteroscedasticity}

Heteroscedasticity is a test to determine whether there is difference residual variance one and another. According to Gujarati (2003) and Ghozali (2005) in Sujarweni (2015), to test heteroscedasticity can use Glejser Test which suggested to regress absolute residual value toward independent variable. In this research, the heteroscedasticity result shown as follows:

Table 7: Glejser Test

Coefficients $^{\mathrm{a}}$

\begin{tabular}{|ll|r|r|r|r|r|}
\hline \multirow{2}{*}{ Model } & \multicolumn{2}{|c|}{ Unstandardized Coefficients } & $\begin{array}{c}\text { Standardized } \\
\text { Coefficients }\end{array}$ & & \\
\cline { 3 - 5 } & & $\mathrm{B}$ & Std. Error & \multicolumn{1}{c|}{ Beta } & \multicolumn{1}{c|}{$\mathrm{t}$} & \multicolumn{1}{c|}{ Sig. } \\
\hline 1 & (Constant) & 2.929 & .418 & & 7.006 & .000 \\
& Efficiency & -.037 & .026 & -.109 & -1.436 & .152 \\
& Reliability & .001 & .036 & .002 & .028 & .978 \\
& System_Availability & -.082 & .032 & -.206 & -2.616 & .009 \\
& Fulfillment & -.008 & .045 & -.015 & -.187 & .852 \\
& Privacy & .036 & .044 & .061 & .812 & .417 \\
\hline
\end{tabular}

a Monondant/ariahlo: shel it

Based on Table 7, there is no heteroscedasticity in Efficiency, Reliability, Fulfillment, and Privacy since the Sig. result is greater than 0.05. Meanwhile, there is heteroscedasticity in System Availability since the result is 0.009 which is less than 0.05 . However, overall data has no heteroscedasticity based on the following figure:

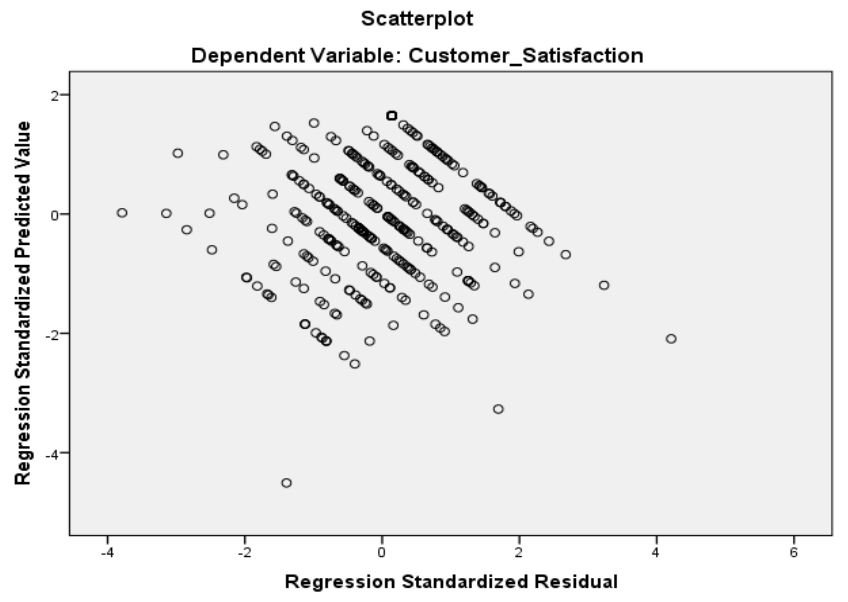

Figure 5: Scatter Plot

Based on Figure 5, the plots were not created a pattern. The existence of heteroscedasticity can be explained through scatterplot. A regression model has no heteroscedasticity when plots are widespread above and below or around 0 . Plots are not allowed to create a pattern, such as wavy, widened, or narrowed. Therefore, there is no heteroscedasticity in this research.

\section{Multiple Regression Analysis}

Multiple regression analysis applied in this research to check whether hypotheses are proved about the impact of e-SQ dimensions that may affect toward Customer Satisfaction partially or even jointly. The calculation of multiple regression analysis in this research processed by SPSS version 23 for Windows. Following is the result of multiple regression analysis:

Table 8: Multiple Regression Analysis

\begin{tabular}{|c|c|c|c|c|c|c|}
\hline \multicolumn{7}{|c|}{ Coefficients $^{\mathrm{a}}$} \\
\hline \multirow{3}{*}{\multicolumn{2}{|c|}{ Model }} & \multicolumn{3}{|c|}{ Unstandardized Standardized } & \multirow[b]{3}{*}{$\mathrm{t}$} & \\
\hline & & \multicolumn{2}{|c|}{ Coefficients } & \multirow{2}{*}{\begin{tabular}{|c|} 
Coefficients \\
Beta \\
\end{tabular}} & & \\
\hline & & B & $\begin{array}{c}\text { Std. } \\
\text { Error }\end{array}$ & & & \\
\hline \multirow[t]{6}{*}{1} & (Constant) & 3.548 & .654 & & 5.421 & .000 \\
\hline & Efficiency & .097 & .040 & .129 & 2.425 & .016 \\
\hline & Reliability & .170 & .057 & .172 & 2.985 & .003 \\
\hline & System_Availability & .196 & .049 & .219 & 3.977 & .000 \\
\hline & Fulfillment & -.056 & .070 & -.043 & -.792 & .429 \\
\hline & Privacy & .488 & .069 & .372 & 7.076 & .000 \\
\hline \multicolumn{7}{|c|}{ a. Dependent Variable: Customer_Satisfaction } \\
\hline
\end{tabular}

Regression model based on Table 8 shown as follows: $\mathrm{Y}=0.129 \mathrm{X} 1+0.172 \mathrm{X} 2+0.219 \mathrm{X} 3-0.043 \mathrm{X} 4+0.372 \mathrm{X} 5$

According to the calculation above, the explanation of equation described as follows:

a) Coefficient regression of Efficiency has positive effect to the customer satisfaction.

b) Coefficient regression of Reliability has positive effect to the customer satisfaction.

c) Coefficient regression of System Availability has positive effect to the customer satisfaction.

\section{Volume 6 Issue 7, July 2017} www.ijsr.net 


\section{International Journal of Science and Research (IJSR) \\ ISSN (Online): 2319-7064}

Index Copernicus Value (2015): 78.96 | Impact Factor (2015): 6.391

d) Coefficient regression of Fulfillment has negative effect to the customer satisfaction.

e) Coefficient regression of Privacy has positive effect to the customer satisfaction.

\section{Hypothesis Testing}

\section{T Test (Partial Test)}

In order to test the regression value model on each variable in partial, the author used t test to get the result. Followings are the result of $t$ test for each variable:

Table 9: $\mathrm{T}$ Test

\begin{tabular}{|c|c|c|c|}
\hline Variable & T Value & Significant Value & Hypothesis \\
\hline Efficiency & 2.425 & 0.016 & Accepted \\
\hline Reliability & 2.985 & 0.003 & Accepted \\
\hline System Availability & 3.977 & 0.000 & Accepted \\
\hline Fulfillment & -0.792 & 0.429 & Rejected \\
\hline Privacy & 7.076 & 0.000 & Accepted \\
\hline
\end{tabular}

F Test

Table 10: F Test

\begin{tabular}{|c|c|c|c|c|c|}
\hline \multicolumn{6}{|c|}{$\mathrm{ANOVA}^{\mathrm{a}}$} \\
\hline Model & Sum of Squares & $\mathrm{df}$ & Mean Square & $\mathrm{F}$ & Sig. \\
\hline Regression & 1134.466 & 5 & 226.893 & 91.046 & $.000^{\mathrm{b}}$ \\
\hline Residual & 944.495 & 379 & 2.492 & & \\
\hline Total & 2078.961 & 384 & & & \\
\hline \multicolumn{6}{|c|}{ a. Dependent Variable: Customer_Satisfaction } \\
\hline & $\begin{array}{r}\text { Fonstant), Privac } \\
\text { Fulfillmen }\end{array}$ & $\begin{array}{l}\text {, Eff } \\
\text { t, Re }\end{array}$ & $\begin{array}{l}\text { iciency, Syster } \\
\text { liability }\end{array}$ & & \\
\hline
\end{tabular}

From the result, it shows that the calculated $F$ value is 91.046 with a significance of $0.000<0.05$. Therefore, Efficiency, Reliability, System Availability, Fulfillment, and Privacy has a positive and significant effect toward customer satisfaction.

\section{Coefficient of Determination $\left(\mathbf{R}^{2}\right)$}

Table 11: Coefficient of Determination Model Summary ${ }^{\mathrm{b}}$

\begin{tabular}{|c|c|c|c|c|}
\hline Model & $\mathrm{R}$ & R Square & \begin{tabular}{|c|} 
Adjusted R \\
Square
\end{tabular} & $\begin{array}{l}\text { Std. Error of the } \\
\text { Estimate }\end{array}$ \\
\hline 1 & $.739^{2}$ & .546 & .540 & 1.57863 \\
\hline
\end{tabular}

Based on the table above, the Adjusted R square is 0.540 which means that $54.6 \%$ of customer satisfaction were affected by Efficiency, Reliability, System Availability, Fulfillment, and Privacy of e-Service Quality. In addition, $45.4 \%$ of customer satisfaction affected by other variables that are applied in this research.

\section{Discussion and Conclusion}

Based on the descriptive analysis conducted on this research, the highest index score is in Customer Satisfaction (Y) with a score of $85 \%$ (very good) while e-Service Quality dimensions (X) such as, Efficiency has index score of $82 \%$ (good), Reliability $82 \%$ (good), System Availability $82 \%$ (good), Fulfillment $83 \%$ (good), and Privacy with a score of $83 \%$ (good).
Based on the statistical analysis through classical assumption test, this research has a normal distribution based on the tests conducted such as Skewness and Kurtosis, Kolmogorov-Smirnov, Normal P-P Plot Graph and P Plot Test. This study has no problem with multicollinearity (nonmulticollinearity) since the result shows all variables has value less than 10, and has no problem with the heteroscedasticity based on the Glejser Test, and Scatter Plot. Based on the multiple regression analysis, all variables show positive impact toward Customer Satisfaction, except for Fulfillment which results a regression model as follows:

$$
Y=0.129 X 1+0.172 \times 2+0.219 \times 3-0.043 X 4+0.372 \times 5
$$

Where,

$\mathrm{X} 1$ : Efficiency

X2: Reliability

X3: System Availability

X4: Fulfillment

X5: Privacy

Based on the hypothesis testing, on t Test (partial test), only Fulfillment has negative impact toward customer satisfaction. The result shown as follows:

Table 12: $T$ Test Discussion

\begin{tabular}{|c|c|c|c|}
\hline Variable & T Value & Sig. Value & Hypothesis \\
\hline Efficiency & 2.425 & 0.016 & Reject H0, Accept H1 \\
\hline Reliability & 2.985 & 0.003 & Reject H0, Accept H2 \\
\hline System Availability & 3.977 & 0.000 & Reject H0, Accept H3 \\
\hline Fulfillment & -0.792 & 0.429 & Accept H0, Reject H4 \\
\hline Privacy & 7.076 & 0.000 & Reject H0, Accept H5 \\
\hline
\end{tabular}

Based on Table 4.18, the highest influence toward Customer Satisfaction is Privacy with T Value of 7.076, followed by System Availability 3.977, Reliability 2.985, Efficiency 2.485, and the lowest influence is Fulfillment with T Value of -0.792 . The more positive of response result, the highest influence for those variables. Based on F Test, all e-Service Quality dimension variables have positive effect toward Customer Satisfaction since the significance value is 0.000 which is less than 0.05. According to Coefficient Determination $\left(\mathrm{R}^{2}\right), 54.6 \%$ of customer satisfaction affected by e-SQ dimensions included in this research and other $45.4 \%$ was affected by other excluded variables.

This research is different among other previous researches since this research target market is PlayStation Store users that bought digital content(s) in PlayStation Store while previous researchers focus was on e-Commerce website that sells physical goods and internet banking service. The framework of this research and previous research are same. Thus, different outcome may occur between this research and previous researches. According to previous research from Saha, P. (2005) and Kania, K. (2015), all of the e-SQ dimension on their research shows a significantly positive impact or effect toward customer satisfaction. Meanwhile, in this research there is one variable that has negative impact toward customer satisfaction, which is the Fulfillment variable. ${ }^{[1]}$ Saha, P. and Zhao, Y. (2005), suggested that to increase the Fulfillment influence is by performing the service right the first time and also provide quick confirmation when the work done. ${ }^{[5]}$

\section{Volume 6 Issue 7, July 2017 www.ijsr.net}




\section{International Journal of Science and Research (IJSR) \\ ISSN (Online): 2319-7064 \\ Index Copernicus Value (2015): 78.96 | Impact Factor (2015): 6.391}

Additionally, Kania, K. (2015) research showed that $86.2 \%$ of customer satisfaction was affected by e-Service Quality dimensions and $13.8 \%$ of customer satisfaction was affected by other variables that are not included in the research ${ }^{[1]}$, while this research only $54.6 \%$ of customer satisfaction affected by e-SQ and other $45.4 \%$ was affected by other excluded variables. This difference indicates that even the same research framework would bring different outcome. The result affected by variables being used in the research and respondent answers as well.

Following are the conclusion:

1) Efficiency has positive effect to the customer satisfaction.

2) Reliability has positive effect to the customer satisfaction.

3) System Availability has positive effect to the customer satisfaction.

4) Fulfillment has negative effect to the customer satisfaction.

5) Privacy has positive effect to the customer satisfaction.

6) Efficiency, Reliability, System Availability, Fulfillment, and Privacy has a positive effect toward customer satisfaction.

7) $54.6 \%$ of PlayStation Store Customer Satisfaction can be explained by Efficiency, Reliability, System Availability, Fulfillment, and Privacy. Other $45.4 \%$ of Customer Satisfaction comes from other variables which are not included in this research.

\section{References}

[1] Kania, K. (2014). The Effect of Online Service Quality to Customer Satisfaction. Telkom University.

[2] Newzoo (2016). Rolling into The Southeast Asian Games Market. [Online]. https://newzoo.com/wpcontent/uploads/2011/06/Newzo o_PG_Connects_Southeast_Asia_V1.pdf $\left[2^{\text {nd }}\right.$ March 2016]

[3] Parasuraman, A., Zeithaml, V. A., and Malhotra, A. (2005). E-S-QUAL A Multiple-Item Scale for Assessing Electronic Service Quality. Journal of Service Research, Volume 7, No. X.

[4] Parasuraman, A., Zeithaml, V. A., and Berry, L. L. (1988). SERVQUAL: A Multiple-Item Scale for Measuring Consumer Perceptions of Service Quality. Volume 64, No. I.

[5] Saha, P. and Zhao, Y. (2005). Relationship Between Online Service Quality and Customer Satisfaction.

[6] Statista (2016). The Most Important Gaming Platforms in 2016.2 [Online]. https://www.statista.com/chart/4527/game-developersplatform-preferences/ [ $2{ }^{\text {nd }}$ September 2016]

[7] Sujarweni, V. W. (2015). METODOLOGI PENELITIAN BISNIS \& EKONOMI. PT. PUSTAKA BARU. Yogyakarta.

[8] TechinAsia (2015). Indonesia is the fastest growing market for games in Southeast Asia. [Online]. https://www.techinasia.com/indonesia-games-southeastasia-newzoo-study [ $2^{\text {nd }}$ March 2016]

[9] VGChartz (2016). Video Game Charts, Game Sales, Top Sellers, Game Data. [Online]. http://www.vgchartz.com $\left[2^{\text {nd }}\right.$ September $2016,11^{\text {th }}$ April 2017]
[10]Zeithaml, V. A., Parasuraman, A., and Malhotra, A. (2002). Service Quality Delivery Through Web Sites: A Critical Review of Extant Knowledge. Journal of the Academy of Marketing Science.

[11]DownDetector (2016). Playstation Network (PSN) down? Current status and problems. [Online]. http://downdetector.com/status/playstation-network[25 ${ }^{\text {th }}$ September 2016]

Volume 6 Issue 7, July 2017 www.ijsr.net 